\title{
Reflexión sobre la reforma del Estado
}

\author{
Manuel Rebollo Puig \\ Catedrático de Derecho Administrativo. Universidad de Córdoba. \\ adlrepum@uco.es
}

Tras oír las brillantes ponencias y las no menos sugerentes intervenciones orales posteriores puede tenerse la impresión de que el Estado social está irremisiblemente tocado y hundido y que escapa a nuestras posibilidades salvarlo. También está afectado el Estado democrático porque muchas de las decisiones más capitales han quedado en manos de poderes sin legitimación democrática. Nuestro Estado autonómico no sale mucho mejor parado... Así, pues, del Estado configurado por la Constitución Española sólo nos quedaría en pie el Estado de Derecho. Éste no es caro ni queda fuera de nuestras posibilidades. Además es el más propio de nuestros dominios como juristas. Pero, la verdad, es que tampoco tengo a este respecto las mejores sensaciones. De un lado, sus instituciones más importantes pasan por un periodo de degradación y de desprestigio creciente que no es del todo debida a una opinión pública desorientada y desanimada sino que tiene fundamentos reales sin que se busquen remedios. Al contrario. Incluso desde ciertos poderes públicos se fomenta y se explota ese desprestigio. Hasta algunos juristas, o falsos juristas, contribuyen a ello. Por otro lado, las normas con rango de ley, incluso las más importantes y vertebradoras, se aprueban con una frivolidad que no favorece lo más mínimo la seguridad jurídica ni la eficacia ni la eficiencia ni, a la postre, el respeto por el Derecho. La reciente Ley de Racionalización y Sostenibilidad de la Administración Local es un buen ejemplo de ello. Sin entrar en el acierto o desacierto de sus pretensiones, lo deleznable es su misma factura y redacción que hace que, sencillamente, no se entienda bien lo que efectivamente instaura. $\mathrm{Ni}$ siquiera en un aspecto tan central como el de las competencias de los municipios. Para pasar de las ideas políticas o de los simplistas esloganes propagandísticos al texto de una norma hace falta algo más de rigor y técnica. Se ha dicho aquí, acaso con exageración, que se encargan anteproyectos de ley a consultoras internacionales que, a su vez, los confían a sus becarios de distintas nacionalidades. Si eso fuese cierto, permítaseme decir que sólo pido que sea el mismo becario el que haga el articulado y las disposiciones finales, adicionales y transitorias porque de lo contrario el resultado final resulta ininteligible.

No puedo dejar de decir algo sobre el Estado social y su supuesta insostenibilidad que sólo tendríamos que aceptar e interiorizar resignadamente. No comparto esa visión según la cual, como hay que hacer indeclinablemente ciertas cosas, por ejemplo, salvar al euro o ser competitivos, y como para ello no tenemos "otras balas", según la expresión que se ha utilizado aquí, nuestro margen de maniobra quedaría constreñido a ir renunciando a las aspiraciones del Estado social. Esa sería la bala que nos queda. No se ha dicho aquí con esa crudeza pero la idea late en el ambiente e incluso, me parece, en nuestro debate. Muy lejos de ello, creo que tampoco esa bala nos queda. No ya porque el Estado social sea una conquista histórica excelente; ni porque no haya el más mínimo desfallecimiento en las convicciones sociales sobre sus valores ni sobre sus aspiraciones; ni porque sea la expresión del más importante pacto entre las fuerzas políticas europeas y la mejor síntesis de sus tendencias contrapuestas; ni porque haya permitido los periodos de mayor paz y estabilidad social y política y el que puede permitirlos en el futuro... No ya por todo eso sino porque como juristas no podemos aceptar que una parte esencial de la Constitución y del pacto que en ella subyace pase al olvido o a lo ilusorio por no se sabe qué fuerzas superiores o por valores o mitos inextricables deificados por no se sabe quién ni cómo. La Constitución sigue consagrando ese Estado social y conteniendo una serie de mandatos que lo concretan y que no han cambiado un ápice. La reforma de su art. 135, aunque afecta profundamente a todo lo demás, no lo deroga ni lo desvanece sino que tiene que conciliarse armoniosamente con todos esos mandatos. Y tampoco el Derecho europeo condena al Estado social. Así que, volviendo a la metáfora, tampoco podemos aceptar que, para lograr ciertos objetivos, nos quede la bala de liquidar el Estado social. El análisis jurídico y el valor normativo que reconocemos a la Constitución lo impiden. 
Lo que sí habrá que hacer es un Estado social más barato, pero no menos social; el Estado social que podamos pagar sin endeudarnos más de lo permitido, sin comprometer las posibilidades de las generaciones futuras y sin arruinar al sistema económico en su conjunto. No caeré en la ingenuidad ni en la demagogia de decir que eso se puede lograr sólo aumentando la eficiencia ni sólo con mayor y nuevas formas de colaboración privada ni sólo con menos corrupción pública y privada... Aunque en todo eso se deba avanzar y aunque también haya que intentar reducir los efectos secundarios nocivos del Estado social, que los tiene, no bastará. Habrá que aceptar que el Estado social modere sus prestaciones; no ya que no crezcan sino que incluso disminuyan, como admiten, y no podría ser de otra forma, todos los Tribunales Constitucionales con sólo muy extremos y difusos límites. Aceptémoslo. Aceptemos, y aquí sí cabe la resignación, que el Estado social dé menos. Pero aceptémoslo precisamente para salvar al mismo Estado social en lo que le es más esencial y sólo en la medida necesaria para lograrlo. Y en eso que le es más esencial ni es necesariamente caro ni de costes inasumibles. Ese aspecto esencial es el que reitera tantas veces nuestra Constitución cuando ordena a los poderes públicos realizar "una asignación equitativa de los recursos públicos" (art. 31.2), promover las condiciones favorables "para una distribución de la renta regional y personal más equitativa" (art. 40.1), "equiparar el nivel de vida de todos los españoles” (art. 130.1), estimular la "más justa distribución" de la renta y la riqueza (art. 131.1) ... y, en suma, "promover las condiciones para que la libertad y la igualdad del individuo y de los grupos en que se integra sean reales y efectivas" (art. 9.2). Es incluso el que se atisba en los Tratados de la Unión Europea cuando tan insistentemente proclaman el valor de la solidaridad y compelen a sus instituciones a combatir la exclusión social y a fomentar la cohesión económica, social y territorial (art. 3 TUE). Es esto lo esencial, lo irrenunciable. Nada de esto ha pasado al museo de la historia del pensamiento político sino que sigue siendo el Derecho positivo del más alto nivel y valor. Cosa distinta es que la realidad parezca ir en otra dirección y que, por ejemplo, según todos los indicadores demuestran, en España, que ya era uno de los países de la Unión Europea con mayor desigualdad, ha aumentado la desigualdad personal y regional, así como el número de personas en situación de pobreza y exclusión social. Pero ante ello no cabe afirmar que Europa o la globalización no nos deja margen de maniobra ni que lo impide la salvación del euro o el nuevo art. 135 de la Constitución, que eso ya desborda nuestras posibilidades. Nada de eso. Más bien creo que es la misma Constitución, con su consagración del Estado social y los preceptos que lo concretan, la que no nos deja margen para no intentar corregirlo; o, al menos, creo que es eso lo que nosotros, como juristas, debemos defender, sin someternos a un extraño determinismo. 